\title{
Comparative morpho-physiological response of in vitro selected somaclones of wheat (Triticum aestivum L.) and explant donor parent to drought stress
}

\author{
Imran Mahmood ${ }^{1 *}$, Abdul Razzaq ${ }^{1}$, Abdul Ahad Qureshi ${ }^{2}$, Abdul Qayyum ${ }^{3}$ and M.M. Qadeer Baig ${ }^{4}$ \\ ${ }^{1}$ Department of Agronomy, Pir Mehr Ali Shah Arid Agriculture University, Rawalpindi-46300, Pakistan. \\ ${ }^{2}$ Department of Horticulture, PMAS-Arid Agriculture University (Sub-campus Khushab), Rawalpindi-46300, Pakistan. \\ ${ }^{3}$ Department of Agronomy, University of Haripur, Haripur, Pakistan. \\ ${ }^{4}$ Adaptive Research Farm Gujranwala, Pakistan.
}

\begin{abstract}
Drought stress is the most prevalent environmental factor limiting wheat productivity globally and demands integration of new plant improvement approaches. Plant tissue culture, being a mutagenic process induces somaclonal variations, which can be manipulated for improving drought tolerance of wheat. An in vitro selection system was employed to regenerate PEG-6000 tolerant callus lines into $\mathrm{R}_{1}$ somaclones. Comparative morpho-physiologcial responses of $\mathrm{R}_{1}$ somaclones and explant donor parent cultivar to osmotic stress were studied at seedling and booting stages by inducing artificial drought stress along with the control of unstressed. Both $\mathrm{R}_{1}$ somaclones and explant donor parent exhibited differential responses to drought stress at both growth stages and the selected somaclones were less affected by drought stress over their donor parent. At seedling stage, the $\mathrm{R}_{1}$ somaclones exhibited significantly higher root length, shoot length, root to shoot length ratio and relative water contents (RWC) under PEG6000 induced osmotic stress. Similarly, at booting stage the $\mathrm{R}_{1}$ somaclones accumulated significantly higher proline, protein, sugar and potassium ion $\left(\mathrm{K}^{+}\right)$contents and maintained higher membrane stability index (MSI) than the original cv. GA-2002 under drought stress conditions. The results revealed that the $\mathrm{R}_{1}$ somaclones of wheat regenerated from PEG-6000 tolerant calli have better drought tolerance than the explant donor parent $\mathrm{cv}$. GA-2002, suggesting that in vitro immature embryo culture can be employed to produce drought tolerant plants of wheat.
\end{abstract}

Keywords: Callus culture, osmotic stress, plant physiology, regeneration, somaclonal variations.

\section{INTRODUCTION}

Wheat is one of the leading cereal crops of the world. It provides $20 \%$ of the world's caloric consumption, and for the $50 \%$ of the world's poorest, $20 \%$ of their protein consumption (Washington Grain Commission, 2015 - 2016). Drought stress adversely affects growth, development and also physiological and biochemical processes, and is a stern threat for sustainable crop production world-wide (Farooq et al., 2009). Half of the world's arable land is arid or susceptible to drought. Thus, it is an imperative aim of the plant breeders to develop drought tolerant cultivars (Mahmood et al., 2014) of cereals to feed the world's ever growing population.

Integration of physiological traits, genetic and genomic tools and transgenic approaches may help to improve resistance against drought in wheat. However, advances in tissue culture techniques, especially callus culture have widened the scope of physiological crop improvement and is an alternative tool for developing stress-tolerant cultivars with limited time, space and cost (Mahmood et al., 2012a; 2014).

During in vitro culture some regenerants appeared to be no longer precise clonal copies of their parents (Prematilake, 2010; Mahmood et al., 2014). The genetic

*Corresponding author(imran_agri@yahoo.com; (iD https://orcid.org/0000-0002-5586-3271) 
or phenotypic variations among such plants are termed as somaclonal variations and sometimes provide a very important source of genetic variations for desired traits including drought tolerance, disease resistance, improved quality, quantity and yield parameters (Matheka et al., 2008; Mahmood et al., 2012a; 2014). The natural variations for drought-tolerance among the somaclones can be exploited in vitro in the presence of a suitable selection pressure of osmotic agent and stress duration (Mahmood et al., 2012b).

The choice of a suitable selection agent with appropriate selection pressure and stress duration is a prerequisite to screen drought tolerant callus lines, and subsequently regenerate them into drought tolerant somaclones (Mahmood et al., 2012b; Verma et al., 2013). Polyethyleneglycol, mol.wt. 6000 (PEG-6000), a non-ionic, non-penetrating and nontoxic water soluble polymer of high molecular weight has long been used for this purpose. It lowers the water potential of the nutrient medium similar to soil drying without being taken up by the plants or being phytotoxic and has been used effectively to explore somaclonal variations for the improvement of crops like maize (El-Aref, 2002; Matheka et al., 2008), wheat (Hsissou \& Bouharmont, 1994; Mahmood et al., 2012a; 2014), rice (Verma et al., 2013) and sugarcane (Taghian, 2002) against drought stress.

Drought tolerance is a complex trait and to validate whether the selected somaclones regenerated from PEG6000 tolerant calli possess higher drought tolerance than the parents, they are to be compared with their donor parents based on various physiological drought tolerance indices (Mahmood et al., 2014).

Visualising the scope of somaclonal variations, the present study was planned to explore the potential of in vitro somaclonal variations for improving drought tolerance of wheat by employing immature embryo culture and PEG-6000 as the screening agent. The morpho-physiological responses of $R_{1}$ selected somaclones and original parents in response to simulated drought stress are discussed.

\section{METHODOLOGY}

\section{Plant material}

The seeds of wheat cultivar GA-2002 (cv. GA-2002) obtained from the National Agricultural Research Centre (NARC) were surface sterilised with $70 \%$ ethanol for 5 min and sown in the pots.

\section{Tissue culture procedure}

The spikes were harvested $2-3$ wks post-anthesis to collect immature embryos. The caryopses were surface sterilised for 5 min with $90 \%$ ethanol followed by washing with three to four changes of sterilised distilled water. The seeds were again sterilised for about $30 \mathrm{~min}$ with $6.5 \%$ solution of $\mathrm{NaOCl}$ containing a few drops of $0.1 \%$ Tween- 20 , followed by thorough washing with sterile distilled water. Immature embryos were removed aseptically and cultured on MS medium (Murashige \& Skoog, 1962) supplemented with $4.0 \mathrm{mgL}^{-1}$ 2,4-D keeping the scutella side upward (Mahmood et al., 2012c). All the tissue culture media were enriched with $30.0 \mathrm{gL}^{-1}$ sucrose and $6.0 \mathrm{gL}^{-1}$ agar. The cultures were enriched at $25 \pm 1{ }^{\circ} \mathrm{C}$ in complete darkness for 3 wks for callus induction. The induced calli were proliferated on MS medium supplemented with $2.0 \mathrm{mgL}^{-1} 2,4-\mathrm{D}$ for another 3 wks. Six explants were cultured in each culture jar of $250 \mathrm{~mL}$ capacity, containing $50 \mathrm{~mL}$ of media. The callus induction and proliferation media were replaced with fresh media after every $12-14 \mathrm{ds}$.

\section{Selection of osmotic stress tolerant calli and regeneration of drought tolerant somaclones ( $R_{0}$ plants) to produce $R_{1}$ seed}

In vitro selection and regeneration procedure for osmotic stress tolerant somaclones $\left(\mathrm{R}_{1}\right)$ reported by Mahmood et al. (2012a; 2014) for wheat was followed. The proliferated calli were divided into micro-clumps of approximately $100.0 \pm 10.0 \mathrm{mg}$ and were cultured on callus selection medium, which is MS medium supplemented with $2.0 \mathrm{gL}^{-1}$ 2,4-D and PEG-6000 induced osmotic stress of - $0.9 \mathrm{MPa}$ for 4 wks to select osmotic stress tolerant callus lines. After 4 wks embryogenic out-growths from the surviving calli were excised and proliferated on fresh callus proliferation medium (MS medium supplemented with $2.0 \mathrm{mgL}^{-1} 2,4-\mathrm{D}$ ) devoid of PEG-6000 for $2 \mathrm{wks}$. The micro-clumps of selected callus pieces were again transferred onto fresh callus selection media for another selection cycle of $4 \mathrm{wks}$ in order to avoid any chance of escaping non-tolerant callus lines. After 2 selection cycles, necrotic tissues were separated from calli and surviving aggregates of cells (callus) were considered osmotic stress tolerant and designated as selected drought tolerant callus lines.

The selected drought tolerant callus lines were cultured on standardised regeneration medium for wheat cv. GA-2002 (MS medium supplemented with $0.5 \mathrm{mgL}^{-1}$ kinetin $+0.2 \mathrm{mgL}^{-1}$ IAA $+0.5 \mathrm{mgL}^{-1}$ BAP) for shoot proliferation and incubated at $26 \pm 1{ }^{\circ} \mathrm{C}$ with $8 \mathrm{~h}$ dark 
and $16 \mathrm{~h}$ light photoperiod. The regenerated shoots were transferred onto half strength MS medium for root induction. The regenerated plantlets $\left(\mathrm{R}_{0}\right)$ were hardened and transferred to earthen pots under control conditions, grown to maturity and selfed to produce $\mathrm{R}_{0}$ seeds.

\section{Appraisal of drought tolerance of $\mathbf{R}_{1}$ somaclones}

Drought tolerance of the selected $\mathrm{R}_{1}$ somaclones (progeny of $\mathrm{R}_{0}$ seeds) was compared with the original parent cv. GA-2002 at seedling stage and booting stage. Accordingly, the $\mathrm{R}_{0}$ seeds of somaclones and seeds of their parent cv. GA-2002 were surface sterilised, germinated in Petri plates for $2-3 \mathrm{ds}$ and cultured in plastic boxes $\left(18 \times 14 \times 4 \mathrm{~cm}^{3}\right)$ filled with sand. Five seedlings were cultured in each box and $100 \%$ field capacity was maintained in the boxes by applying distilled water. One week after transferring the seedlings into boxes, out of the total, half number of the boxes were provided with half-strength Hoagland solution containing $20 \%$ PEG$6000(\mathrm{~V} / \mathrm{W})$ as stressing agent, while the remaining half number was kept as control (no PEG-6000 added). The plants were then supplied with distilled water to maintain $100 \%$ field capacity daily for $15 \mathrm{ds}$ after transferring the seedlings into the boxes, and various drought adopted seedling traits like root length $(\mathrm{cm})$, shoot length $(\mathrm{cm})$, root to shoot length ratio (root:shoot) and relative water content (RWC) were recorded.

In the $2^{\text {nd }}$ step of the study, the germinated seeds were established, uniform seedlings were selected and transferred into earthen pots of $18.5 \mathrm{~L}$ capacity $(\mathrm{r}=14 \mathrm{~cm}$; $\mathrm{h}=30 \mathrm{~cm}$ ) filled with sandy loam soil. Three pots per treatment and 4 plants per pot were maintained and were provided with equal amount of water daily to maintain $100 \%$ field capacity. After 6 wks of seedling transfer into the pots (booting stage), drought stress was induced by withholding water completely for a specific period and sampling was done on the $2^{\text {nd }}, 4^{\text {th }}, 6^{\text {th }}$ and $8^{\text {th }}$ day of withholding water to study the physiological responses of plants. At the $9^{\text {th }}$ day of withholding water, the leaves of both $\mathrm{R}_{1}$ somaclones and parent cultivar showed severe symptoms of wilting and no further sampling was carried out. Sampling was also done at zero day of drought (control). The following physiological drought indices were studied.

\section{Relative water content (RWC) of seedling}

The plants were uprooted with intact roots and fresh weight $\left(\mathrm{F}_{\mathrm{w}}\right)$ was immediately taken. Then the plants were submerged for $4 \mathrm{~h}$ in distilled water at room temperature under constant light. After soaking for $4 \mathrm{~h}$ turgid weight $\left(\mathrm{T}_{\mathrm{w}}\right)$ was taken. The plants were then dried for $36 \mathrm{~h}$ at
$70{ }^{\circ} \mathrm{C}$ for dry weight $\left(\mathrm{D}_{\mathrm{w}}\right)$. Plant RWC was estimated as:

$\operatorname{RWC}(\%)=\left[\frac{\mathrm{F}_{\mathrm{w}}-\mathrm{D}_{\mathrm{w}}}{\mathrm{T}_{\mathrm{w}}-\mathrm{D}_{\mathrm{w}}}\right] \times 100$

\section{Free proline content ( $\mu \mathrm{molg}^{-1}$ fr. wt.)}

The free proline content was estimated by the method of Bates et al. (1973) using toluene as blank. Leaf samples $(500.0 \mathrm{mg})$ were crushed and homogenised in $3 \%$ sulfosalicylic acid $(5.0 \mathrm{~mL})$ with the help of mortar and pestle. The homogenised samples were filtered (Whatman no. 1 filter paper) and volume of the filtrate was raised to $10.0 \mathrm{~mL}$ with sulfosalicylic acid. Then, to $2.0 \mathrm{~mL}$ of the extract in a test tube $2.0 \mathrm{~mL}$ of ninhydrin reagent and 2.0 $\mathrm{mL}$ of glacial acetic acid (1.25 g of ninhydrin dissolved in a blend of $20.0 \mathrm{~mL}$ of ortho-phosphoric acid and $30.0 \mathrm{~mL}$ of glacial acetic acid) was added. The resultant mixture was boiled for a period of $30 \mathrm{~min}$ in a water bath at $100{ }^{\circ} \mathrm{C}$. After cooling the reaction mixture, $6.0 \mathrm{~mL}$ of toluene was added and mixed thoroughly. After mixing, the chromophore containing toluene was separated and absorbance of the sample was recorded against toluene blank at $520 \mathrm{~nm}$ by spectrophotometer (Optima, SP 3000 plus).

\section{Total soluble sugar content (mgg-1 dry wt.)}

The total soluble sugar content was estimated from dry leaf samples by phenol sulphuric acid reagent method described by Dubois et al. (1951). Leaf samples $(0.5 \mathrm{~g})$ were extracted in phosphate buffer, $1.0 \mathrm{~mL}$ of extract was mixed with $0.5 \mathrm{~mL}$ of $5 \%$ phenol solution and then $2.5 \mathrm{~mL}$ of $96 \%$ sulphuric acid was added rapidly. The tube was gently agitated during acid addition and then allowed to stand in a water bath at $26-30^{\circ} \mathrm{C}$ for $20 \mathrm{~min}$. The absorbance of coloured solution was measured at $490 \mathrm{~nm}$ by spectrophotometer (Optima, SP 3000 plus) using glucose as the standard.

\section{Total soluble protein content (mgg ${ }^{-1}$ dry wt.)}

Total soluble protein content was determined by employing the method of Lowry et al. (1951). The dried leaf sample $(250.0 \mathrm{mg})$ was macerated with $10.0 \mathrm{~mL}$ of phosphate buffer solution. The content was centrifuged at $3000 \mathrm{rpm}$ for $10 \mathrm{~min}$ and the supernatant was collected and made up to $25.0 \mathrm{~mL}$. To $1.0 \mathrm{~mL}$ of the supernatant, $5.0 \mathrm{~mL}$ of alkaline copper tartarate reagent and $0.5 \mathrm{~mL}$ of folin reagent were added. The colour intensity was measured at $660 \mathrm{~nm}$ (spectrophotometer; Optima, SP 3000 plus) and soluble protein was quantified by using bovine serum albumin as the standard. 


\section{Potassium content (mgg-1 dry wt.)}

Dried and ground leaf samples $(1.0 \mathrm{~g})$ were collected in $100 \mathrm{~mL}$ flasks and $25.0 \mathrm{~mL}$ of $1.0 \mathrm{~N} \mathrm{HCl}$ was added. The flasks were stored for $24 \mathrm{~h}$ and filtered using Whatman no. 1 filter paper. $\mathrm{K}^{+}$content of the filtrate was estimated by flame photometer using $\mathrm{K}^{+}$standards $(0,20,40,60,80$ and 100 ppm; Yoshida et al., 1972).

\section{Chlorophyll content (mgg-1 fresh wt.)}

A fresh sample of leaves was ground with mortar and pestle in $80 \%$ acetone and was kept at room temperature for $3-4 \mathrm{~h}$ in dark to avoid any photobleaching and for complete extraction of pigments. The mixture was centrifuged at $12000 \mathrm{rpm}$ and absorbance of the supernatant was measured by spectrophotometer. For chlorophyll a and chlorophyll b absorbance (A) was recorded at $647 \mathrm{~nm}$ and $664 \mathrm{~nm}$, respectively using PFP7 flame photometer. Total chlorophyll was quantified by the method of Coombs et al. (1987).

Total chlorophyll = 7.93 A664 + 19.53 A647

\section{Percentage leaf membrane stability index (MSI)}

Percentage leaf membrane stability index was estimated by adopting the method used by Chandrasekar et al. (2000). Double distilled water $(10.0 \mathrm{~mL})$ was taken separately in two different sets of test tubes. Leaf samples (200.0 mg) cut into fine pieces were added to each set of test tubes. One set of test tubes was heated at $40{ }^{\circ} \mathrm{C}$ for $30 \mathrm{~min}$ in a water bath and electrical conductivity of the sample was recorded $\left(\mathrm{C}_{1}\right)$. The second set of test tubes was incubated for $15 \mathrm{~min}$ at $100{ }^{\circ} \mathrm{C}$ in a water bath and their electrical conductivity (EC) was recorded as above $\left(\mathrm{C}_{2}\right)$. MSI was calculated by using the following formula:

MSI $\%=\left[1-\frac{C_{1}}{C_{2}}\right] \times 100$

\section{Layout of experiment and data analysis}

The first experiment was designed as completely randomised design (CRD) and the second experiment (pot trail) was laid out following randomised complete block design (RCBD) with factorial arrangement repeated thrice. The data were analysed using Statistix 8.1.1.0 software and treatment means were compared by least significant difference (LSD) test at $\alpha=0.05$.

\section{RESULTS AND DISCUSSION}

Water deficit is a severe environmental stress affecting plant productivity with an evident effect on plant growth and development. The morpho-physiological responses of $\mathrm{R}_{1}$ somaclones and explant donor parent cv. GA-2002 were studied at seedling and booting stages in response to $20 \%$ PEG-6000 and various durations of drought stress, respectively.

Osmotic stress at the seedling stage of both $\mathrm{R}_{1}$ somaclones and explant donor parent cv. GA-2002 showed pronounced effect on root length (RL), shoot length (SL) root to shoot length ratio (root:shoot) and RWC of seedlings, with significant decrease in the studied traits compared with the control. Under controlled conditions, non-significant differences were witnessed for the studied traits. The $\mathrm{R}_{1}$ somaclones showed significantly higher RL and SL and maintained higher RWC in response to $20 \%$ PEG-6000 than the explant donor parent cv. GA-2002. However, the mean values of shoot length did not differ significantly at seedling stage in response to PEG induced osmotic stress (Table 1).

Drought stress of various durations at booting stage significantly influenced proline contents. A significant increase in proline contents was observed in leaf tissues of both $\mathrm{R}_{1}$ somaclones and explant donor parent cv. GA2002 in response to increasing duration of osmotic stress (Figure 1). Significantly higher proline contents were witnessed in the leaf samples of $\mathrm{R}_{1}$ somaclones collected on the $4^{\text {th }}, 6^{\text {th }}$ or $8^{\text {th }}$ day of water stress with corresponding proline contents of $4.02,6.3$ and $7.52 \mu \mathrm{molg}^{-1}$ fr.wt., respectively. Nevertheless, non-significant differences were recorded for proline contents under control conditions and for stress duration of 2 days. Similarly, an increasing trend was observed for protein accumulation with escalated duration of water stress up to 6 days. However, the protein contents of the leaf samples of both $\mathrm{R}_{1}$ somaclones and their explant donor parent cv. GA2002 collected on the $8^{\text {th }}$ day of stress were declined. The $\mathrm{R}_{1}$ somaclones tend to accumulate the highest protein content (4.36 $\mu_{\mathrm{molg}}{ }^{-1}$ dry wt.) in response to water stress of 6 days, which were significantly higher than the parents at the same level of water stress $\left(3.58 \mu \mathrm{molg}^{-1}\right.$ dry wt.; Figure 2).

The sugar and $\mathrm{K}^{+}$contents tend to increase with increasing severity of water stress. Stress-induced increase in sugar contents by the $\mathrm{R}_{1}$ somaclones and 
parent cv. GA-2002 was more comparable on the $4^{\text {th }}, 6^{\text {th }}$ and $8^{\text {th }}$ day of withholding water (Figure 3 ), showing significantly more sugar accumulation by the $\mathrm{R}_{1}$ somaclones than the explant donor parent. Similarly, the $\mathrm{K}^{+}$contents of both $\mathrm{R}_{1}$ somaclones and their parent cv. GA-2002 were increased with increasing duration of water stress (Figure 4 ). The $\mathrm{K}^{+}$contents of $\mathrm{R}_{1}$ somaclones (14.77 $\mathrm{mgg}^{-1}$ dry wt.) and their parent (15.33 $\mathrm{mgg}^{-1}$ dry wt.) were statistically at par under control conditions and varied significantly in response to $2^{\text {nd }}, 4^{\text {th }}, 6^{\text {th }}$ and $8^{\text {th }}$ day of water stress being higher in $R_{1}$ somaclones (Figure 4).

Table 1: Response of $\mathrm{R}_{1}$ somaclones and explant donor parent $\mathrm{cv}$. GA-2002 to PEG-6000 induced osmotic stress at seedling stage

\begin{tabular}{|c|c|c|c|}
\hline & Control & PEG-6000 & Mean \\
\hline \multicolumn{4}{|l|}{ Root length (cm) } \\
\hline Parent cv. GA-2002 & $14.32 \mathrm{a}$ & $8.31 \mathrm{c}$ & $11.32 \mathrm{~b}$ \\
\hline $\mathrm{R}_{1}$ somaclones & $14.36 \mathrm{a}$ & $10.67 b$ & $12.52 \mathrm{a}$ \\
\hline Mean & $14.34 \mathrm{a}$ & $9.50 \mathrm{~b}$ & \\
\hline \multicolumn{4}{|l|}{ Shoot length $(\mathrm{cm})$} \\
\hline Parent cv. GA-2002 & $16.77 \mathrm{a}$ & $12.94 \mathrm{c}$ & $14.86 \mathrm{a}$ \\
\hline $\mathrm{R}_{1}$ somaclones & $16.31 \mathrm{a}$ & $14.62 b$ & $15.47 \mathrm{a}$ \\
\hline Mean & $16.54 \mathrm{a}$ & $13.78 b$ & \\
\hline \multicolumn{4}{|l|}{ Root: Shoot } \\
\hline Parent cv. GA-2002 & 0.854 & 0.643 & $0.748 b$ \\
\hline $\mathrm{R}_{1}$ somaclones & 0.882 & 0.730 & $0.806 \mathrm{a}$ \\
\hline Mean & $0.868 \mathrm{a}$ & $0.686 \mathrm{~b}$ & \\
\hline \multicolumn{4}{|l|}{ RWC } \\
\hline Parent cv. GA-2002 & $86.42 \mathrm{a}$ & $76.60 \mathrm{c}$ & $81.51 \mathrm{~b}$ \\
\hline $\mathrm{R}_{1}$ somaclones & $85.99 a$ & $82.29 \mathrm{~b}$ & $84.14 \mathrm{a}$ \\
\hline Mean & $86.21 \mathrm{a}$ & $79.44 b$ & \\
\hline \multicolumn{4}{|l|}{ LSD Values } \\
\hline & Plant & & \\
\hline & material (P) & Stress (S) & $\mathrm{P} \times \mathrm{S}$ \\
\hline Root & 0.5662 & 0.5662 & 0.8007 \\
\hline Shoot & $0.7223^{\mathrm{NS}}$ & 0.7223 & 1.0215 \\
\hline Root:Shoot & 0.0535 & 0.0535 & $0.0757^{\mathrm{NS}}$ \\
\hline RWC & 2.5102 & 2.5102 & 3.5499 \\
\hline
\end{tabular}

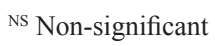

Entries sharing similar letters do not differ significantly at $5 \%$ probability level

The osmotic stress significantly affected leaf chlorophyll contents and a progressive decline in chlorophyll dynamics was observed with rising episode of water

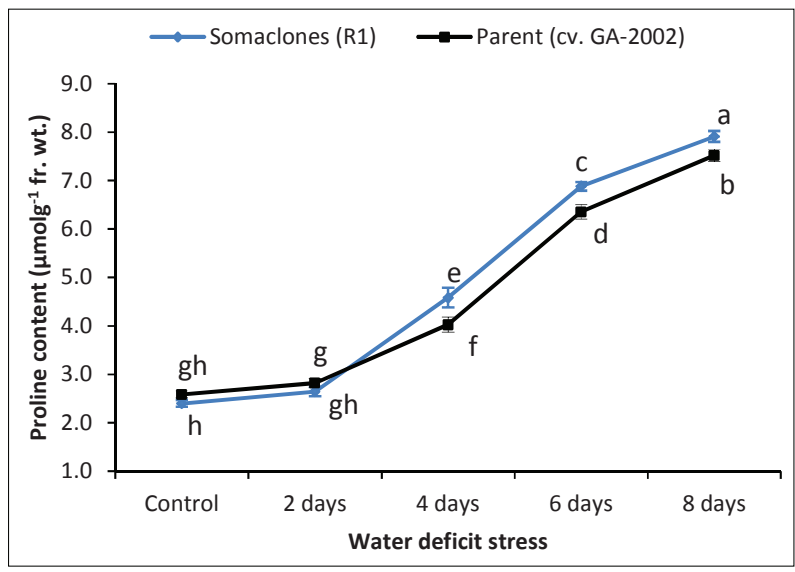

Figure 1: Proline contents ( $\mu \mathrm{molg}^{-1}$ fr. wt.) of $\mathrm{R}_{1}$ somaclones and their parent wheat $\mathrm{cv}$. GA-2002 in response to various durations of water stress at booting stage. Vertical bars represent standard errors. Bars sharing similar letters do not differ significantly $(\mathrm{p}<0.05)$

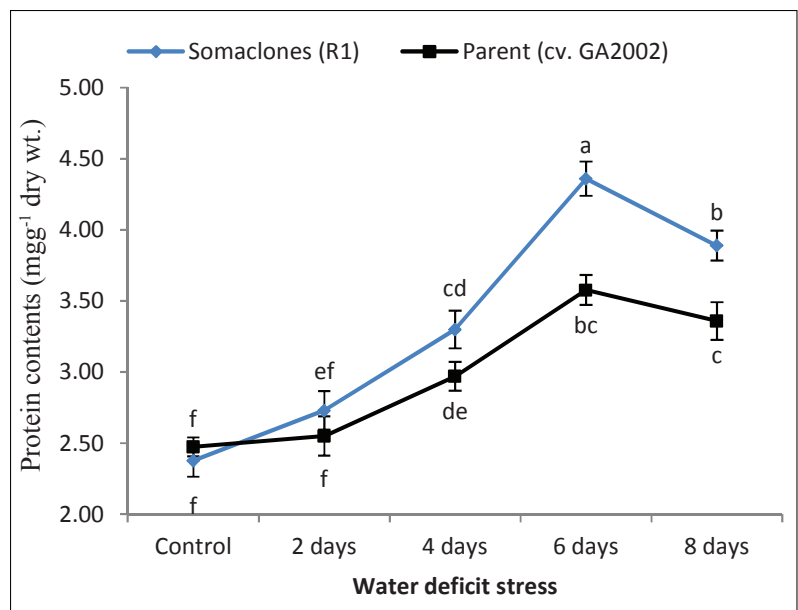

Figure 2: Protein contents ( $\mathrm{mgg}^{-1}$ dry wt.) of $\mathrm{R}_{1}$ somaclones and their parent wheat cv. GA-2002 in response to various durations of water stress at booting stage. Vertical bars represent standard errors. Bars sharing similar letters do not differ significantly $(\mathrm{p}<0.05)$

stress (Table 2). The maximum chlorophyll content (mean) was recorded in control plants $\left(2.89 \mathrm{mgg}^{-1} \mathrm{fr}\right.$. wt.) whereas the minimum $\left(1.30 \mathrm{mgg}^{-1} \mathrm{fr}\right.$. wt. $)$ was on the $8^{\text {th }}$ day of water stress. However, non-significant differences were recorded for mean chlorophyll contents of $\mathrm{R}_{1}$ somaclones and parent cv. GA-2002 subject to osmotic stress (Table 2). Similarly, a declining trend was also observed for MSI in response to escalated duration of water stress showing mean maximum MSI under control 
conditions and the least on $8^{\text {th }}$ day of water stress. The mean MSI (74.51\%) of $\mathrm{R}_{1}$ somaclones was significantly higher than that of parent cv. GA-2002 $(71.07 \%)$ in response to simulated water stress (Table 2).

Table 2: Comparative physio-chemical responses of in vitro selected $\mathrm{R}_{1}$ somaclones and their parent cv. GA-2002 in response to simulated water stress of various durations at booting stage

\begin{tabular}{|c|c|c|c|c|c|c|}
\hline & \multicolumn{5}{|c|}{ Water stress in days } & \multirow[b]{2}{*}{ Mean } \\
\hline & Control & 2 days & 4 days & 6 days & 8 days & \\
\hline \multicolumn{7}{|c|}{ Chlorophyll contents ( $\mathrm{mgg}^{-1}$ fr. wt.) } \\
\hline Parent cv. GA-2002 & 2.94 & 2.83 & 2.41 & 1.85 & 1.25 & 2.26 \\
\hline $\mathrm{R}_{1}$ somaclones & 2.84 & 2.81 & 2.49 & 1.98 & 1.35 & 2.30 \\
\hline Mean & $2.89 \mathrm{a}$ & $2.82 \mathrm{a}$ & $2.45 b$ & $1.92 \mathrm{c}$ & $1.30 \mathrm{~d}$ & \\
\hline \multicolumn{7}{|c|}{ Leaf membrane stability index (MSI) } \\
\hline Parent cv. GA-2002 & 85.11 & 81.57 & 74.32 & 64.68 & 49.65 & $71.07 \mathrm{~b}$ \\
\hline $\mathrm{R}_{1}$ somaclones & 86.31 & 83.56 & 77.91 & 70.56 & 54.19 & $74.51 \mathrm{a}$ \\
\hline Mean & $85.71 \mathrm{a}$ & $82.57 \mathrm{a}$ & $76.11 b$ & $67.62 \mathrm{c}$ & $51.92 \mathrm{~d}$ & \\
\hline \multicolumn{7}{|l|}{ LSD values } \\
\hline & \multicolumn{2}{|c|}{ Plant material $(\mathrm{P})$} & Stress (S) & \multicolumn{2}{|l|}{$\mathrm{P} \times \mathrm{S}$} & \\
\hline Chlorophyll contents & \multicolumn{2}{|c|}{0.057 Ns } & $0.090^{*}$ & \multicolumn{2}{|l|}{$0.128^{\mathrm{NS}}$} & \\
\hline MSI & \multicolumn{2}{|c|}{$2.011 *$} & $3.180^{*}$ & \multicolumn{2}{|l|}{$4.496^{\mathrm{NS}}$} & \\
\hline
\end{tabular}

Ns Non-significant; * significant

Entries sharing similar letters do not differ significantly at $5 \%$ probability level

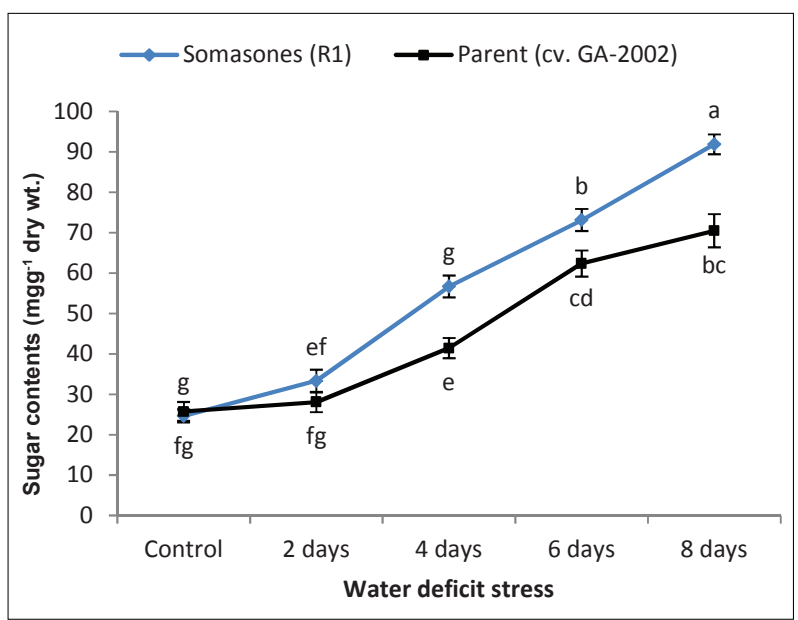

Figure 3: Sugar contents ( $\mathrm{mgg}^{-1}$ dry wt.) of $\mathrm{R}_{1}$ somaclones and their parent wheat cv. GA-2002 in response to various durations of water stress at booting stage. Vertical bars represent standard errors. Bars sharing similar letters do not differ significantly $(\mathrm{p}<0.05)$

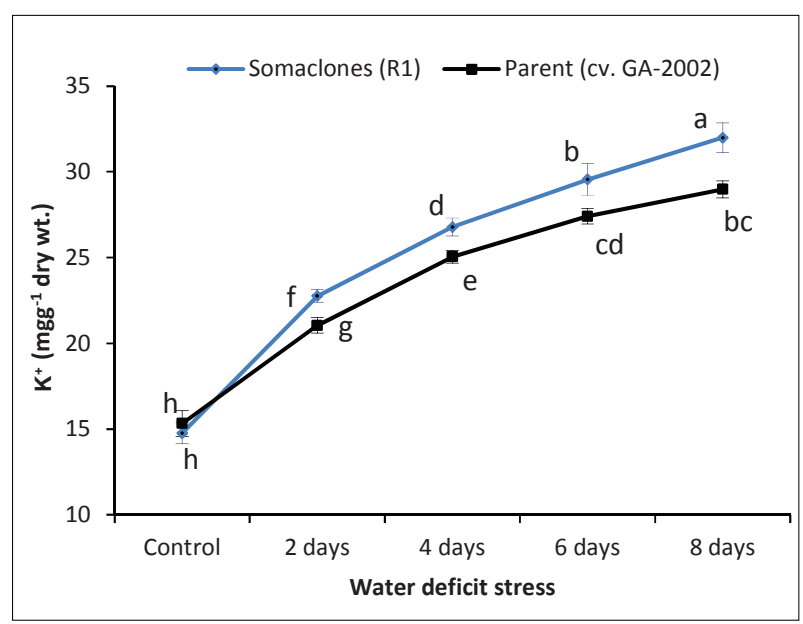

Figure 4: $\mathrm{K}^{+}$contents ( $\mathrm{mgg}^{-1}$ dry wt.) of $\mathrm{R}_{1}$ somaclones and their parent wheat $\mathrm{cv}$. GA-2002 in response to various durations of water stress at booting stage. Vertical bars represent standard errors. Bars sharing similar letters do not differ significantly $(\mathrm{p}<0.05)$ 
Drought has significant effects on the physiology of cereal crops. The plants demonstrate various morphological, physiological, biochemical and molecular responses to tackle drought stress. At morphological level, shoot and root growth, its density, proliferation and size are most affected and are the key components of plant adaptation to drought (Farooq et al., 2009). Retarded shoot growth and increased root growth are the morphological adaptive traits in plants under water stress conditions (Dhanda et al., 2004). The root and shoot length of wheat plant decrease in response to moisture deficit stress, while root to shoot length ratio increase compared with that of well watered plants (Safarnejad, 2004). In wheat, up to $40 \%$ increase in root to shoot length ratio has been reported in stressed plants compared to control. The increase in root to shoot dry matter/length ratio under water deficit conditions is not due to the increase in root mass but rather due to reduced shoot mass (Dhanda et al., 2004). The results of the present study suggested that root and shoot growth was suppressed more in explant donor parent cv. GA-2002 in response to simulated water stress showing that they are more susceptible to drought. The findings are in accordance with earlier reports suggesting that somaclones regenerated from PEG tolerant calli are more drought tolerant due to better root and shoot growth under osmotic stress conditions (Safarnejad, 2004; Verma et al., 2013).

Under water deficit conditions at the metabolite level, amino acids, most notably proline increase to provide osmoprotective functions, prevent dissociation of enzymes and safeguard the cell from reactive oxygen species (ROS) (Kumar et al., 2011; Mehmood-ul-Hassan et al., 2013). Accordingly, genotypes which accumulate more proline are less prone to adverse effects of drought stress (Chandrasekar et al., 2000; Qayyum et al., 2017). The selected somaclones are also reported to accumulate more proline than parents with improved stress tolerance (Safarnejad, 2004; Verma et al., 2013).

Proteins and lipids are the major constituents of membranes. Drought induced metabolic changes associated with protein turnover have shown that rubisco, rubisco binding protein (RBP), rubisco activase (RA), dehydrins (DHN), ATP dependent calpain protease (Clp) proteins and some heat shock proteins (HSP) are substantially increased in both drought tolerant and susceptible cultivars of wheat in response to drought stress, with higher increment in tolerant ones (Demirevska et al., 2008; Qayyum et al., 2017). Therefore, under drought conditions, the protein contents are increased substantially in the root and shoot tissues of wheat (Tayeb \& Ahmed, 2010) affirming the results of the present study (Figure 2). The tendency of the $R_{1}$ somaclones to accumulate more protein content than the parent cv. GA-2002 (Figure 2) depicted their better drought tolerance.

Other than proline and protein, sugars also play a pivotal role in osmotic adjustment without inhibiting activity of the enzymes and ensure survival of plants under water deficit conditions. In addition, sugars help to stabilise the membrane system and keep proteins intact and functional under drought conditions (Sinay \& Karuwal, 2014) and are thereby considered a reliable marker for assessing the level of drought tolerance in wheat (Cheng et al., 2015). The results showed an increasing trend for sugar accumulation and the response was more pronounced against moisture stress of $4^{\text {th }}, 6^{\text {th }}$ and $8^{\text {th }}$ days, with significantly higher sugar contents portrayed by $R_{1}$ somaclones (Figure 3 ). A significant increment in the soluble sugar content of drought tolerant and sensitive genotypes has been reported in response to drought stress (Marcińska et al., 2013; Cheng et al., 2015; Qayyum et al., 2017). However, drought tolerant genotypes/plants tend to accumulate more soluble sugar contents than sensitive ones (Marcińska et al., 2013; Qayyum et al., 2017).

In addition, traits expected to improve adaptation of wheat to the Mediterranean environment also included accumulation of potassium in the leaves (Kusvuran, 2012). Potassium plays a pivotal role in economical yield, growth, protein biosynthesis, enzyme activation, photosynthesis, transpiration, stomatal regulation and osmotic adjustment (Farooq \& Azam, 2001; Farooq et al., 2009). It is anticipated that about $60 \%$ of osmotic adjustment in both mature and expanding leaves of wheat is accomplished by potassium salts (Kusvuran, 2012). Wheat genotypes differ in their ability to accumulate $\mathrm{K}^{+}$ and the genotypes which tend to accumulate relatively more $\mathrm{K}^{+}$under water deficit conditions tend to endure drought stress in a better way (Farooq \& Azam, 2001; Zhu et al., 2005). Undifferentiated cell/callus lines of drought tolerant genotypes of wheat are also reported to accumulate more intracellular $\mathrm{K}^{+}$than sensitive ones (Trivedi et al., 1991). Significantly higher accumulation of $\mathrm{K}^{+}$by the $\mathrm{R}_{1}$ somaclones than the parent cv. GA-2002 with mounting duration of water stress (Figure 4) showed that they are more drought tolerant, and it is supported by the findings of Begum and Islam (2015).

The chlorophyll content provides insight regarding photosynthesis particularly under water deficit conditions. Over production of ROS is triggered by excessive energy absorption by the photosynthetic apparatus and is avoided 
by the plants through degradation of light absorbing pigments accompanied by increased reflectance of the incident radiation by changing the green colour of the leaf into yellow (Kumar et al., 2011) and is considered an important drought adaptive trait. Hence, water stress results in pigment degradation and leads to irreversible damage to the photosynthetic machinery/chlorophyll (Bogale et al., 2011). Therefore, chlorophyll contents tend to decline with increasing severity of drought stress (Chandrasekar et al., 2000; Kumar et al., 2011). The chlorophyll contents of $R_{1}$ somaclones and parent cv. GA-2002 declined with increasing duration of water stress (Table 2) and is in conformity with previous reports (Chandrasekar et al., 2000; Kumar et al., 2011; Razzaq et al., 2013a; 2013b). Under drought conditions, the drought sensitive plants lose chlorophyll and senescenced earlier than drought tolerant ones (Saeedipour \& Moradi, 2011). Accordingly, the genotypes which maintain higher chlorophyll contents under limited supply of moisture are considered more drought tolerant (Chandrasekar et al., 2000; Saeedipour \& Moradi, 2011). The regenerated somaclones $\left(R_{1}\right)$ did not show improved chlorophyll stability than their explant donor parent under water stress conditions (Table 2), since the somaclones are not always superior to explant donor parents for most of the agronomic and quality parameters (Hanson et al., 1994). Contrary to the above, some reports have shown variations in chlorophyll contents of regenerated clones of wheat (Yasmin et al., 2009). For example, Hsissou and Bouharmont (1994) regenerated drought tolerant plants of durum wheat with improved chlorophyll fluorescence, mainly because of differences of protocol and plant material used. It is revealed that $\mathrm{R}_{1}$ somaclones may cope with water stress by different adaptive strategies other than chlorophyll stability index; given that, drought tolerance is a complex trait and all drought adopted traits are not always expressed simultaneously in every drought tolerant genotype (Chandrasekar et al., 2000).

Soil moisture deficit also results in dehydration of the cells accompanied by electrolyte leakage due to strain exerted by increased intercellular concentration of solutes on membranes and macromolecules. The membrane stability index (MSI) is a measure of the intactness of the membranes' structure against electrolyte leakage under drought stress conditions, and the index of membrane injury is proportional to the post desiccation electrolyte leakage from the membrane systems (Ali et al., 2009). Proteins and lipids are the major constituents of membranes. Reactive oxygen species (ROS), predominantly hydrogen peroxide $\left(\mathrm{H}_{2} \mathrm{O}_{2}\right)$ and superoxide radicals are increased under soil moisture deficit conditions and cause oxidative damage to proteins, nucleic acids and lipids (Al-Ghamdi, 2009), thereby interrupt association between the lipid and protein bilayer. Therefore, membrane systems are the major loci prone to desiccation injury, and the transport ability of the membranes is impaired. Many reports suggested that the MSI declines with increasing moisture deficit stress (Chandrasekar et al., 2000; Razzaq et al., 2013a; 2013b). However, drought tolerant genotypes are shown to maintain a higher MSI than drought susceptible ones (Chandrasekar et al., 2000). The ability of the $\mathrm{R}_{1}$ somaclones to maintain higher MSI than the parent cv. GA-2002 (Table 2) showed that they are more drought tolerant. Hsissou and Bouharmont (1994) have also regenerated drought tolerant somaclones of wheat from osmotic stress tolerant callus lines with less electrolyte leakage (high membrane stability) than parental lines.

Based on the morpho-physiological responses of $\mathrm{R}_{1}$ somaclones and explant donor parent $\mathrm{cv}$. GA-2002 under drought conditions, it is evident that $\mathrm{R}_{1}$ somaclones regenerated from PEG-6000 tolerant callus lines have improved drought tolerance than the parent line. It is likely that the surviving tolerant calli may acclimate to osmotic stress when exposed to two consecutive passages and the cellular components of stress tolerance were inherited to $\mathrm{R}_{1}$ somaclones thereafter (Lutts et al., 2001). The improved drought tolerance of $R_{1}$ somaclones is also in accordance with the findings of many other researchers. For example, drought tolerant somaclones $\left(\mathrm{R}_{1}\right.$ and $\left.\mathrm{R}_{2}\right)$ of sugarcane were developed by Taghian (2002) using PEG-6000 or $\mathrm{NaCl}$ as stressing agents. Mahmood et al. (2012a; 2014) and Verma et al. (2013) screened PEG-6000 osmotic stress tolerant calli of wheat and rice, respectively, and regenerated drought tolerant plants thereafter from selected callus lines. Similarly, drought tolerant somaclones of maize were regenerated from PEG-6000 tolerant calli by El-Aref (2002) and Matheka et al. (2008).

\section{CONCLUSION}

The ability of the in vitro selected $\mathrm{R}_{1}$ somaclones to exhibit more root length, shoot length, root to shoot length ratio and RWC under simulated drought stress at seedling stage, and to accumulate relatively higher osmolites, $\mathrm{K}^{+}$contents and to maintain relatively higher MSI in response to drought stress at booting stage than the explant donor parent cv. GA-2002 indicated their improved drought tolerance. The study signifies that immature embryo culture in the presence of a suitable concentration of osmoticum can be employed to exploit somaclonal variation for improving drought tolerance 
of wheat. It is suggested that to confirm whether the acquired drought tolerance of $\mathrm{R}_{1}$ somaclones is of genetic or epigenetic nature, the stability of drought tolerance based on morpho-physiological drought adapted traits and yield parameters should be tested in $R_{2}$ and $R_{3}$ generations.

\section{REFERENCES}

Al-Ghamdi A.A. (2009). Evaluation of oxidative stress tolerance in two wheat (Triticum aestivum) cultivars in response to drought. International Journal of Agriculture and Biology 11: 7 - 12 .

Ali M.A., Abbas A., Niaz S., Zulkiffal M. \& Ali S. (2009). Morpho-physiological criteria for drought tolerance in sorghum (Sorghum bicolor) at seedling and post-anthesis stages. International Journal of Agriculture and Biology 11: $674-680$.

Bates L.S., Waldorn R.P. \& Teare I.D. (1973). Rapid determination of free proline for water stress studies. Plant and Soil 39: 205 - 208.

DOI: https://doi.org/10.1007/BF00018060

Begum M.K. \& Islam M.O. (2015). Selection of salt tolerant somaclones for development of salt stress tolerant varieties. Plant 3(4): 37 - 46.

DOI: https://doi.org/10.11648/j.plant.20150304.12

Bogale A., Tesfaye K. \& Geleto T. (2011). Morphological and physiological attributes associated to drought tolerance of Ethiopian durum wheat genotypes under water deficit condition. Journal of Biodiversity and Environmental Sciences 1(2): 22 - 36.

Chandrasekar V., Sairam R.K. \& Srivastava G.C. (2000). Physiological and biochemical responses of hexaploid and tetraploid wheat to drought stress. Journal of Agronomy and Crop Science 185(4): 219 - 227.

DOI: https://doi.org/10.1046/j.1439-037x.2000.00430.x

Cheng Z., Dong K., Ge P., Bian Y., Dong L., Deng X., Li X. \& Yan Y. (2015). Identification of leaf proteins differentially accumulated between wheat cultivars distinct in their levels of drought tolerance. PLOS ONE 10(5): e0125302. DOI: https://doi.org/10.1371/journal.pone.0125302

Coombs J., Hall D.O., Long S.P. \& Scurlock S.M.O. (1987). Chlorophyll determination. Techniques in Bioproductivity and Photosynthesis, pp. 22. Pergamon Press, Oxford, UK.

Demirevska K., Simova-Stoilova L., Vassileva V., Vaseva I., Grigorova B. \& Feller U. (2008). Drought-induced leaf protein alterations in sensitive and tolerant wheat varieties. General and Applied Plant Physiology (Special Issue) 34(1 - 2): $79-102$.

Dhanda S.S., Sethi G.S. \& Behl R.K. (2004). Indices of drought tolerance in wheat genotypes at early stages of plant growth. Journal of Agronomy and Crop Science 190: 6 - 12. DOI: https://doi.org/10.1111/j.1439-037X.2004.00592.x

Dubois M., Gilles K., Hamilton J.K., Rebers P.A. \& Smith F. (1951). A colorimetric method for the determination of sugars. Nature 168: $167-168$.

DOI: https://doi.org/10.1038/168167a0
El-Aref H.M. (2002). Employment of maize immature embryo culture for improving drought tolerance. Proceedings of the $3^{\text {rd }}$ Scientific Conference of Agriculture Sciences, Faculty of Agriculture, Assiut University, Assiut, Egypt, 20 - 22 October, pp. $463-477$.

Farooq S. \& Azam F. (2001). Co-existence of salt and drought tolerance in Triticeae. Hereditas 135: 205 - 210. DOI: https://doi.org/10.1111/j.1601-5223.2001.00205.x

Farooq M., Wahid A., Kobayashi N., Fujita D. \& Basra S.M.A. (2009). Plant drought stress: effects, mechanisms and management. Agronomy for Sustainable Development 29(1): $185-212$.

DOI: https://doi.org/10.1051/agro:2008021

Hanson K., Hucl P. \& Baker R.J. (1994). Comparative field performance of tissue culture derived lines and breeder lines of HY320 spring wheat. Plant Breeding 112(3): $183-191$. DOI: https://doi.org/10.1111/j.1439-0523.1994.tb00669.x

Hsissou D. \& Bouharmont J. (1994). In vitro selection and characterization of drought tolerant plants of durum wheat (Triticum durum Desf.). Agronomie 14(2): 65 - 70. DOI: https://doi.org/10.1051/agro:19940201

Kumar R.R., Karajo 1.K. \& Naik G.R. (2011). Effect of polyethylene glycol induced water stress on physiological and biochemical responses in pigeonpea (Cajanuscajan $L$. Millsp.). Recent Research in Science and Technology 3(1): $148-152$.

Kusvuran S. (2012). Influence of drought stress on growth, ion accumulation and antioxidative enzymes in okra genotypes. International Journal of Agriculture and Biology 14(3): $401-406$.

Lowry O.H., Rosebrough N.J., Farr A.L. \& Randall R.J. (1951). Protein measurement with the Folin phenol reagent. The Journal of Biological Chemistry 193: 265 - 275.

Lutts S., Kinet J.M. \& Bouharmont J. (2001). Somaclonal variation in rice after two successive cycles of mature embryo derived callus culture in the presence of $\mathrm{NaCl}$. Biologia Plantarum 44(4): 489 - 495. DOI: https://doi.org/10.1023/A:1013761814407

Mahmood I., Razzaq A., Ashraf M., Hafiz I.A., Kaleem S., Qayyum A. \& Ahmad M. (2012a). In vitro selection of tissue culture induced somaclonal variants of wheat for drought tolerance. Journal of Agricultural Research 50(2): 177 - 188 .

Mahmood I., Razzaq A., Hafiz I.A., Kaleem S., Khan A.A., Qayyum A. \& Ahmad M. (2012b). Interaction of callus selection media and stress duration for in vitro selection of drought tolerant callus of wheat. African Journal of Biotechnology 11(17): 4000 - 4006.

Mahmood I., Razzaq A., Khan Z.U.D., Hafiz I.A. \& Kaleem S. (2012c). Evaluation of tissue culture responses of promising wheat (Triticum aestivum L.) cultivars and development of efficient regeneration system. Pakistan Journal of Botany 44(SI): $277-284$.

Mahmood I., Razzaq A., Rasheed M., Qayyum A. \& Ahmad M. (2014). Employment of immature embryo culture for in vitro selection of drought tolerant somaclones of wheat. Bulgarian Journal of Agricultural Science 20(1): 155 - 161. 
Marcińska I. et al. (12 authors) (2013). Impact of osmotic stress on physiological and biochemical characteristics in drought-susceptible and drought-resistant wheat genotypes. Acta Physiologiae Plantarum 35: 451 - 461. DOI: https://doi.org/10.1007/s11738-012-1088-6

Matheka J.M., Magiri E., Rasha A.O. \& Machuka J. (2008). In vitro selection and characterization of drought tolerant somaclones of tropical maize (Zea mays L.). Biotechnology 7(4): $641-650$.

DOI: https://doi.org/10.3923/biotech.2008.641.650

Mehmood-ul-Hassan, Qayyum A., Razzaq A., Ahmad M., Mahmood I., Khan S.U. \& Jenks M.A. (2013). Evaluation of maize cultivars for drought tolerance based on physiological traits associated with cell wall plasticity. Jokull Journal 63(7): 466 - 478.

Murashige T. \& Skoog F. (1962). A revised medium for rapid growth and bio assays with tobacco tissue cultures. Physiologia Plantarum 15: 473 - 497.

DOI: https://doi.org/10.1111/j.1399-3054.1962.tb08052.x

Prematilake D.P. (2010). Inducing genetic variation of innala (Solenostemon rotundifolius) via in vitro callus culture. Journal of the National Science Foundation of Sri Lanka 33(2): $123-131$.

DOI: https://doi.org/10.4038/jnsfsr.v33i2.2342

Qayyum A. et al. (13 authors) (2017). Water stress effects on biochemical traits and antioxidant activities of wheat (Triticum aestivum L.) under in vitro conditions. Acta Agriculturae Scandinavica, Section B-Soil and Plant Science 68(4): 283 - 290. DOI: https://doi.org/10.1080/09064710.2017.1395064

Razzaq A., Ali Q., Qayyum A., Mahmood I., Ahmad M. \& Rasheed M. (2013a). Physiological responses and drought resistance index of nine wheat (Triticum aestivum L.) cultivars under different moisture conditions. Pakistan Journal of Botany 45(SI): 151 - 155.

Razzaq A., Mahmood I., Iqbal J., Qayyum A., Rasheed M. \& Ahmad M. (2013b). Enhancing drought tolerance of wheat (Triticum aestivum L.) through chemical priming. Wulfenia Journal 20(7): $44-58$.

Saeedipour S. \& Moradi F. (2011). Relationship between abscisic acid (ABA) concentration and some physiological traits in two wheat cultivars differing in post-anthesis drought resistance. African Journal of Biotechnology 10(72): 16219 - 16227.
DOI: https://doi.org/10.5897/AJB11.2269

Safarnejad A. (2004). Characterization of somaclones of Medicago sativa L. for drought tolerance. Journal of Agricultural Science and Technology 6: 121 - 127.

Sinay H. \& Karuwal R.L. (2014). Proline and total soluble sugar content at the vegetative phase of six corn cultivars from Kisar Island Maluku, grown under drought stress conditions. International Journal of Advance Agricultural Research 2: $77-82$.

Taghian A.S. (2002). Expression of mutual tolerance to drought and salt stresses of the in vitro selected clones of sugarcane, Proceedings of the $3^{\text {rd }}$ Scientific Conference of Agriculture Sciences, Faculty of Agriculture, Assiut University, Assiut, Egypt, 20 - 22 October, pp. $441-262$.

Tayeb M.A.E. \& Ahmed N.L. (2010). Response of wheat cultivars to drought and salicylic acid. American-Eurasian Journal of Agronomy 3(1): 1 - 7.

Trivedi S., Galiba G., Sankhla N. \& Erdei L. (1991). Responses to osmotic and $\mathrm{NaCl}$ stress of wheat varieties differing in drought and salt tolerance in callus cultures. Plant Science 73(2): $227-232$.

Verma D., Ansari M.W., Agrawal G.K., Rakwal R., Shukla A. \& Tuteja N. (2013). In vitro selection and field responses of somaclonal variant plants of rice cv PR113 for drought tolerance. Plant Signaling and Behavior 8(4): e23519. DOI: https://doi.org/10.4161/psb.23519

Washington Grain Commission (2015 - 2016). Washington wheat facts. 2015 - 2016. Available at http://wagrains. org/wp-content/uploads/2015/04/WGC-201516WF4WebFinal.pdf.

Yasmin S., Khan I.A., Khatri A., Seema N., Nizamani G.S. \& Arain M.A. (2009). In vitro plant regeneration in bread wheat (Triticum aestivum L.). Pakistan Journal of Botany 41(6): 2869 - 2876.

Yoshida S., Forno D.A., Cock J.H. \& Gomez K.A. (1972). Laboratory Manual for Physiological Studies of Rice, $2^{\text {nd }}$ edition. International Rice Research Institute, The Philippines.

Zhu X., Gong H., Chen G., Wang S. \& Zang C. (2005). Different solute levels in two spring wheat cultivars induced by progressive field water stress at different developmental stages. Journal of Arid Environments 62: 1 - 14. DOI: https://doi.org/10.1016/j.jaridenv.2004.10.010 